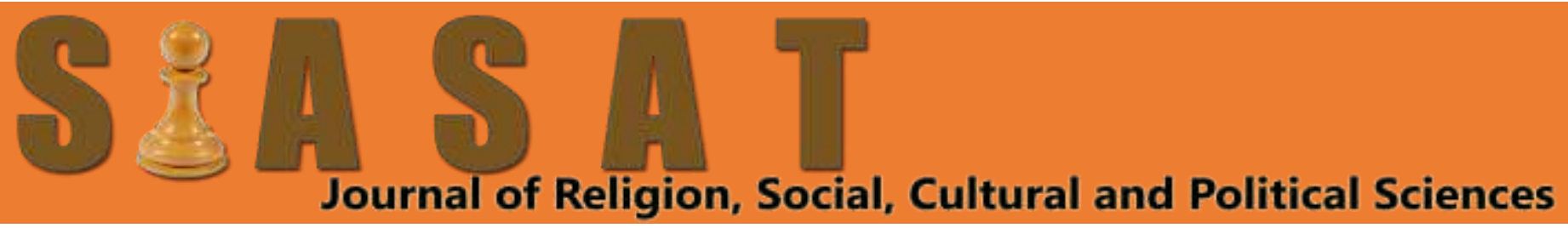

\title{
Interpretation Verse of Religious Moderation: Systematic Library Review Meaning of Ummatan Wasathan in Qs. 2: 143
}

\author{
Muhammad Faisal Hamdani \\ Universitas Islam Negeri Sumatera Utara, Indonesia \\ hamdanim1014@gmail.com
}

\section{Abstract}

This study focuses on examining the interpretation of the verse on religious moderation, related to the term wastahan ummatan in QS.Al Baqarah (2): 143. This research is important in knowing the views of commentators on the Qur'anic verse regarding religious moderation and related to the contemporary context. This research uses a qualitative traditional approach, using a literature review through a systematic review method of references (Systematic Library Research) related to the focus of this study. The data analysis technique used in this study is descriptive, interpretive and deductive analysis which is carried out in stagesfformulation, search, inspection/selection, analysissynthesis, quality control mainstreaming, and report preparation.
Keywords

Interpretation; verse; religious moderation; ummatan wasatan

\section{Introduction}

In the era of digital technology and social media, the life of inter-religious relations in Indonesia is really facing challenges. The incoming information is unstoppable without a filter, coupled with the rapid internalization of instant knowledge, including religious knowledge and disturbing the fortress of togetherness and national weaving. Ideally, the spirit of religious moderation will inspire us to always be balanced and fair in formulating our perspectives, attitudes and behavior, not to commit violence in the name of any kind, whether religious separatism or human rights.

Importance this study was made, as an effort to rearrange the interpretation of the verse related to religious moderation, along with the context of space and time that underlies the emergence of that interpretation. Of course, by linking it with the current context, especially Indonesia, a more relevant interpretation can be taken, and of course it does not deviate from the rules of the science of interpretation and prioritizes the benefit of the life of the nation and state. Through this study hope you can contribute ideas as an alternative interpretation of religious moderation, especially in the context of tolerance and inter-religious harmony.

\section{Research Method}

In collecting data, this study uses a qualitative approach with the Systematic Literature Review (SLR) method, namely by searching and selecting books of interpretation and other references related to religious moderation, especially verses related to the focus of this study. The analysis used in this research is descriptive, interpretive and deductive. That is, the opinion of the mufassirin, will be organized, classified and reinterpreted. The unit of analysis in this research is the entire opinion of scholars and academics, especially in the field of commentary on the interpretation of the QS. 2: 143 which was recorded on the google search engine.Related to the descriptive analysis used in 
SIASAT Journal of Social, Cultural and Political Studies, 7 (1) January 2022, 71-81

ISSN: 2721-7469 (Print), 2721-7450 (Online)

Muhammad Faisal Hamdani: Interpretation Verse of Religious Moderation: Systematic Library Review Meaning of Ummatan Wasathan in Qs. 2: 143

https://siasatjournal.com/index.php/siasat

this study, as the unit of analysis, the opinion of the scholars and mufassirin about Qs. 2:143 will be compared according to the context of the past and the present context, especially Indonesianness.

\section{Result and Discussion}

Allah SWT said QS. al-Baqarah (2): 143: "And thus We have made you the Ummatan Wasathan (middle people) so that you may be witnesses/examples of human (deeds) and that the Messenger (Muhammad) may be witnesses/examples of your (deeds). now) but that We may know (in the real world) who followed the Messenger and who disobeyed. And indeed (the change of Qibla) is very heavy, except for those who have been guided by Allah; and Allah will not waste your faith. Verily, Allah is Most Gracious, Most Merciful to mankind."Researchers in the phenomenological view try to understand the meaning of events and their relation to ordinary people in certain situations. Phenomenological sociology is basically strongly influenced by the views of Edmund Husserl and Alfred Schultz. Another influence comes from Weber who put pressure on versteheen, namely interpretive understanding of human understanding. Phenomoenology does not assume that researchers know the meaning of something to the people being studied.

Because of the above nuzul verse, it was narrated by Muqatil that a group of Jews said: "Our Qibla is the Qibla of the Prophets, and we have done justice among people," they confessed. They even protested about the diversion of the Qibla from Bait Maqdis towards the Grand Mosque, because they considered themselves the most moderate and had done justice among humans. For them, it is not appropriate for the mecca of Muslims to be moved to Mecca. (As-Suyuthi, 2008:29) Thus, this verse is a firm refutation of the claims and assumptions of the Jews as the best people, because only Islam has received wasath recognition in the sight of Allah SWT. (Al-Jawziyyah, 2001: 115).

There are also many hadiths related to the word wasath or those with the same root as wustha and awsath, including the following 3 hadiths: (Arif, 2020: 27-28):

1. From Abu Sa'id said; The Prophet sallallaahu 'alaihi wasallam said: "(On the day of qiyamat) Noah 'alaihissalam and his people came and Allah Ta'ala said: "Have you conveyed (teachings)?. Noah 'Alaihissalam replied: "Yes, O my Lord." Then Allah asked his ummah: "Is it true that he has conveyed to you?". They replied; "No. No prophet came to us." Then Allah said to Noah 'alaihissalam: "Who is a witness against you?". Prophet Nuh Alaihissalam said: "Muhammad SAW and his ummah". the message that he carried to his ummah. That is what Allah Most High has said (Surat alBaqarah verse 143, which means, "And thus we have made you a middle community to be witnesses over mankind...",al-washath means al-'adl (fair). (Narrated by Bukhari, Hadith No. 3091 and Ahmad, Hadith No. 10646).

2. From Ibn Abbas the Prophet SAW said: "When food has been served, then take it from the side and leave the middle, indeed the blessing comes down in the middle "(HR. Ibn Majah. Hadith No. 3268).

3. From Abdullah bin Muawiyah Al Ghadhiri he said; The Prophet SAW said: "Three things, whoever does it, he will feel the pleasure of faith, namely whoever worships Allah alone and there is no god worthy of worship except Allah, and pays zakat on his wealth with an open soul and his soul is motivated to pay zakat. every year and do not give animals that are old and have lost teeth, weak, and sick or pay for it with a small ugly one.midfor verily Allah does not ask for your best wealth nor does He command you to give the worst wealth" (Narrated by Abu Dawud. Hadith No. 1349). 
Minister of Religion Lukman Hakim Saifudin on the sidelines of the Ministry of Religion's National Work Meeting last January 2019, ordered his staff to adhere to three mantras in carrying out their duties, namely first, religious moderation, second, togetherness, and third, improving the quality of religious services.

Wasath meaning, etymologically: Something that is in the middle, or something that has two ends of equal size. Terminology: Islamic values that are built on the basis of a straight and middle mindset, are not excessive in certain respects. (Ibn 'Assyria, 1984:1718). 'Adulan, khyaran, simple and selected. (Dhoif, 1972: 1061). According to the Merriam-Webster Dictionary (digital dictionary), moderation is defined as avoiding extreme behavior and expressions. A moderate person is someone who stays away from extreme behaviors and expressions. (Choir, Fanani, et al, 2009:468). While the meaning of Wasathiyah (moderate understanding), is a characteristic of Islam that is not shared by other religions, calls for tolerant Islamic da'wah, opposes all forms of liberal and radical thought. The characteristics of a moderate Muslim's understanding and practice of religious practice: 1. Tawassuth (taking the middle way); 2. Tawazun (balanced); 3.I'tidal (straight and firm); 4. Tasamuh (tolerance); 5. Musawah (egalitarian); 6. Shura (consultation); 7. Ishlah (reform); 8. Alawiyah (put priority); 9. Tathawwur wa Ibtikar (dynamic and innovative); 10. Tahaddhur (civilized).

Term means a just people, who are not one-sided in both the world and the hereafter, but are balanced between the two. From the word wasath, comes the word referee in Indonesian which means; 1). Intermediary, intermediary (in the field of business or trade etc.), 2). Determiner, leader (in a football match for example), 3. Separator, mediator (if there is a dispute in the match). The word wasath has a good and commendable meaning, in contrast to the word al-tarf which means edge, this word has a negative connotation because those who are on the edge will easily slip. In the Qur'an, the word wasatha is only found 3 times in the Qur'an, namely wasatan (sura al-Baqarah: 143), awsatha (sura alQalam: 28) and wusthaa (sura al-Baqarah: 238). From the three verses above, the Qur'an talks about moderation in general/global in scope. Among the desired moderation is moderation in faith, worship and religious symbols, social and community relations, morality, education and others. (Budiono, 2001:85)

John M. Echols and Hassan Shadily (2003: 384) say, moderation comes from the word moderation /'mad $\square$ 'raiseen/kb; Moderate attitude, no exaggeration. Moderator/'mad $\square$ 'rait $\square$ r; chairman (meeting) mediator, mediator (of dispute). Al-Wasthu, fair and middle; more than that is called tafriith and taqshiir (too restrictive or narrow). These last two traits are highly reprehensible. Of the three, the most noble is wasath (middle). It means not excessive, not outrageous and not restrictive. Az-Zijaz said that the word wasathan has two meanings, namely 'adlan wa khiyaaran (fair and middle). The two words are different but have the same meaning, namely, fair is in the middle and in the middle means fair. Among them is the wustha prayer, as stated in His word: Keep your prayer and (maintain) the wustha prayer. As stated in His word: "Pay attention to your prayers and (maintain) wustha prayers"And stand (in your prayers) solemnly'." (Surat alBaqarah 2:238). (Ministry of Religion of the Republic of Indonesia, 2010:21, in Qasim, 2020: 38-39). The word wasathiyah was absorbed into Indonesian as a regulator or mediator of competition by sport with the same basic letter as the ism fa'il "referee." Wustha prayer after prayer in general means showing the specialization and importance of maintaining and caring for the wustha prayer. The wustha prayer is the middle and most important prayer. (Jabbar and Burhanuddin, 2012:713)

The concept of religious moderation is built from two terms, the word moderation and the word religion. Moderation, literally from the Latin Moderatio, which means moderate (no excess 
and no deficiency), also means self-control (from an attitude of very excess and lack). The Big Indonesian Dictionary (KBBI) defines the word moderation as: 1. reducing violence, and 2. avoiding extremes. In English, the word moderation is often used in the sense of average, core, standard, or non-aligned. So, moderate can mean promoting balance in beliefs, morals, and character, when treating others as individuals, or when dealing with state institutions. In Arabic, moderation is known as wasath or wasathiyah, which has the same meaning as tawassuth (middle), i'tidal (fair), and tawazun (balanced).

Wasatiyyahis the concept of balance in living life, both in the worldly and hereafter dimensions, with the effort of objectively adjusting to the situation at hand, based on religious instructions and provisions. The concrete form of moderate attitude in religion is the balance between the spirit and the body, the world and the hereafter, religion and the state, the individual and society, ideas and reality, the old and the new, reason and naqal (religious texts), religion and science, modernity and tradition., etc. The indicator of the principle of religious moderation is the existence of cooperation and mutually tolerant agreements towards existing differences. (Budiono, 2001:85)

The person who applies the principle of wasathiyah is called wasith. The word wasith has been absorbed into Indonesian into the word 'wasit' which has three meanings, namely: 1) intermediary, intermediary (eg in trade, business); 2) mediator (separator, reconciler) between the disputants; and 3) the leader in the match. According to etymology, moderation is an attitude and view that is not excessive, not extreme and not radical (tatharruf). QS. al-Baqarah (2): 143, which explains the superiority of Muslims over other people. The Qur'an teaches balance and moderation is also emphasized. Muslims are people who are able to act fairly and good people. The term religion, literally means to adhere to (embracing) religion, to worship; obedient to religion; good in life (according to religion) and very venerable; fond of; emphasize (conversational words). The term religion is understood as spreading peace and love, anytime, anywhere and to anyone. Religion is not to homogenize diversity, but to respond wisely. Religion exists so that human dignity, status and dignity are guaranteed and protected. Religion is interpreted as protecting the heart, behavior of oneself, the whole country and the universe. Religious moderation means a moderate perspective in religion, namely understanding and practicing religious teachings not to the extreme, either right or left. Indicators of religious moderation are measured from three (3) benchmarks, namely: (1) Religious adherents return to the main core of religious teachings, namely human values; and (2) mutual agreement, showing cooperation among diverse, complementary human beings; and (3) public order, which gave birth to a moderate religious atmosphere. Research entitledDevelopment of Diverse Moderation in Religious Education Institutions (The Ministry of Religion's Simlitbangdiklat) recommends that: (1) Formulation of the concept of moderation by indicators that are agreed upon and understood by each of the different religious perspectives and equalized perceptions; to society at large; (2) Internalization of the concept of religious moderation; (2) Socialization of religious moderation. (Ministry of Religion Purbalingga, 2021).

In Islamic tradition, Prophet Muhammad SAW strongly encouraged his followers to always take the middle way, which is believed to be the best way. The Prophet SAW said: "The best of affairs is the middle way." In Indonesia, wasathiyah discourse or Indonesian moderation, wasathiyah discourse or moderation is often described through three pillars of moderation, namely: thoughts, movements and actions. (Kemenag RI, 2019: 26-28) 


\subsection{Interpretation QS al Baqarah (2): 143}

Based on the results of the search, verification, review and assessment of 30 research results related to the interpretation of QS al Baqarah (2): 143 (hereinafter abbreviated asQS. 2:143, pen.) is linked in the context of religious moderation, in accordance with the protocol and established keywords, namely, a study of the meaning of wasathan in the interpretations that have been researched in the last 10 years (2011-2021), then the mapping of the concept of the interpretation of the verse can be described as stated in the following table.

Review of Research on Tafsir QS al Baqarah (2): 143 Associated with Moderation Context

\begin{tabular}{|c|c|c|}
\hline No & Interpretation & The Meaning of Ummah and Wasathan in the Context of Moderation \\
\hline \multicolumn{3}{|l|}{1} \\
\hline 2 & Al Asfahaniy & $\begin{array}{l}\text { The word moderation in Arabic means al-wasathiyah. In language, al- } \\
\text { wasathiyah comes from the word wasath. Wasath is interpreted sawa"un, } \\
\text { middle, between two boundaries, with justice, the standard or the } \\
\text { mediocre. Wasathan: Keeping from being uncompromising even leaving } \\
\text { the line of religious truth. (Mussafa, 2018:19-21,33-35) }\end{array}$ \\
\hline \multicolumn{3}{|l|}{3} \\
\hline & Al Maraghi & $\begin{array}{l}\text { Moderate Islam views the Qur'an as an open book, rejecting the view of the } \\
\text { Qur'an as a closed and textualistic book. (Mide, 2014: 72).QS. 2:143 has } \\
\text { correlation with the previous paragraph. This verse explains the } \\
\text { moderation of Muslims that before the arrival of Islam there were two } \\
\text { groups, the right and the left. First, the Jews who put forward the physical } \\
\text { and benefit the body. Second, groups who are too busy with spiritual } \\
\text { affairs, too resigned to the traditions of their ancestors, such as the } \\
\text { Christians, al-Shabi'ah and Wathniyyah are among this group.(Budiono: } \\
\text { 101-102) }\end{array}$ \\
\hline 4 & Alusiy & $\begin{array}{l}\text { Two important things inQS.2:143: First, the mention of ummah wasathan } \\
\text { as an indication of the superiority of Muslims. Second, the advantage of } \\
\text { the Qibla towards the Haram mosque is as good as the best Qibla on earth. } \\
\text { According to him, the superiority of the ummah is not only in the } \\
\text { hegemony of Muslims today, but before the earlier believers also received } \\
\text { guidance to the straight path (al-sirath al-mustaqim). (Budiono: 99) }\end{array}$ \\
\hline 5 & Al Qurtubi & $\begin{array}{l}\text { At-Tirmidzî narrated from Sa'en Al-Khudrî, from the Prophet SAW, } \\
\text { regarding the word of Allah SWT; "And so (also) we have made you } \\
\text { (Muslims), a just and chosen people. "Abu Sa"id said, "(namely the } \\
\text { ummah) who fair, At-Tirmidzî said "This hadith is a hadith" } \square \text { asan } \\
\square \text { a } \square \text { i } \square \text {,"In the Qur'an it is stated, "Says one of the best in mind } \\
\text { among them" (Qs. Al-Qalam [68]: 28) That is, the most just and the best of } \\
\text { them. That is, the ummah (Islam) is not excessive as the ummah of } \\
\text { Na } \square \text { exaggeration with their prophets, nor did they transgress the limits of } \\
\text { the Jewish Ummah with their prophets. Al-Wasat is azh-zharf (container). } \\
\text { You said, "sallaitu Was } \square \text { a Al-Qaum (I pray in the midst of the people). } \\
\text { Jalastu wasata ad-dârî } \square \text { (I'm sitting in the middle House). (Hozaituna, } \\
\text { 2019:31-32) The Word of Allah SWT, "And so (also) We have made you } \\
\text { (Muslims) a chosen and chosen Ummah." The meaning of this word of } \\
\text { God adalah, as Ka'even though it is in the middle of the earth, so shall we } \\
\text { also made you middle class people. That is, we made you below prophets }\end{array}$ \\
\hline
\end{tabular}




\begin{tabular}{|c|c|c|}
\hline & & $\begin{array}{l}\text { but above the (other) peoples. Meaning of al-Wasahis fair. Origin of the } \\
\text { word this is, that the most commendable thing is the middle. Wasathan is } \\
\text { justice, because the best thing is the most just. Sayal-wustha in QS 2:238, } \\
\text { shape feminism from the word wasath, means best and fairest. People } \\
\text { wasathan is a just and best people because the best thing is the most just. } \\
\text { Allah swt wants Muslims to be moderate, fairest and most intelligent } \\
\text { people. That Muslims must be people who are always in a middle and } \\
\text { moderate position, not in an extreme or excessive position. (Arif, 2020: } 30 \text {, } \\
25-26,40 \text { ) Allah commands to hold fast to the Qur'an and al-Sunnah as } \\
\text { well as congregations in practicing Islam, then with this agreement and } \\
\text { unity will be reached which is the main requirement for the good of the } \\
\text { world and the hereafter. (Mide, 2014: } 73 \text { ). }\end{array}$ \\
\hline 6 & $\begin{array}{l}\text { al Razi, al } \\
\text { Sabt } \quad(2003: \\
239)\end{array}$ & $\begin{array}{l}\text { Even though they have similarities in the obligations of servanthood to } \\
\text { Allah with the previous people, Allah SWT specializes Muslims with the } \\
\text { addition of glory and honor to become ummah wasathan as a gift from } \\
\text { Allah (Budiono, 2001:93). }\end{array}$ \\
\hline & As-Shabuni & $\begin{array}{l}\text { According to Ali as-Shabuni, Wasathan Ummah are the chosen people and } \\
\text { can act justly, and will be witnesses on the Day of Resurrection that the } \\
\text { Messenger has sent them to deliver his message. (Rizky \& Zakiah,2020:3) }\end{array}$ \\
\hline 7 & As Shalaby & $\begin{array}{l}\text { Abdurrahman As-Sa'diy and Rashid Rida interpret that the meaning of } \\
\text { wasathan in QS. 2:143 is justice and goodness." Ibnul Jauzy, I mean QS } \\
2: 238 \text { there are } 3 \text { meanings: } 1 \text { : Regarding the prayer which is located in the } \\
\text { middle, second: the middle of the size, and third: because the most afdhal } \\
\text { position." "Says the one who is the best in mind among them: "Didn't I tell } \\
\text { you, you should glorify (to your Lord)?" (Surat al-Qalam: } 28 \text { ) "And the } \\
\text { horses of war rushed into the midst of the enemy group" (Surah Al-Adiyat: } \\
\text { 5) At-Tabari, Al-Qurtubi and Al-Qasimi said: The meaning is to be in the } \\
\text { midst of the enemy "(Arif, 2020: 25-26.30-32.40) }\end{array}$ \\
\hline 8 & At Tabari ${ }^{1}$ & 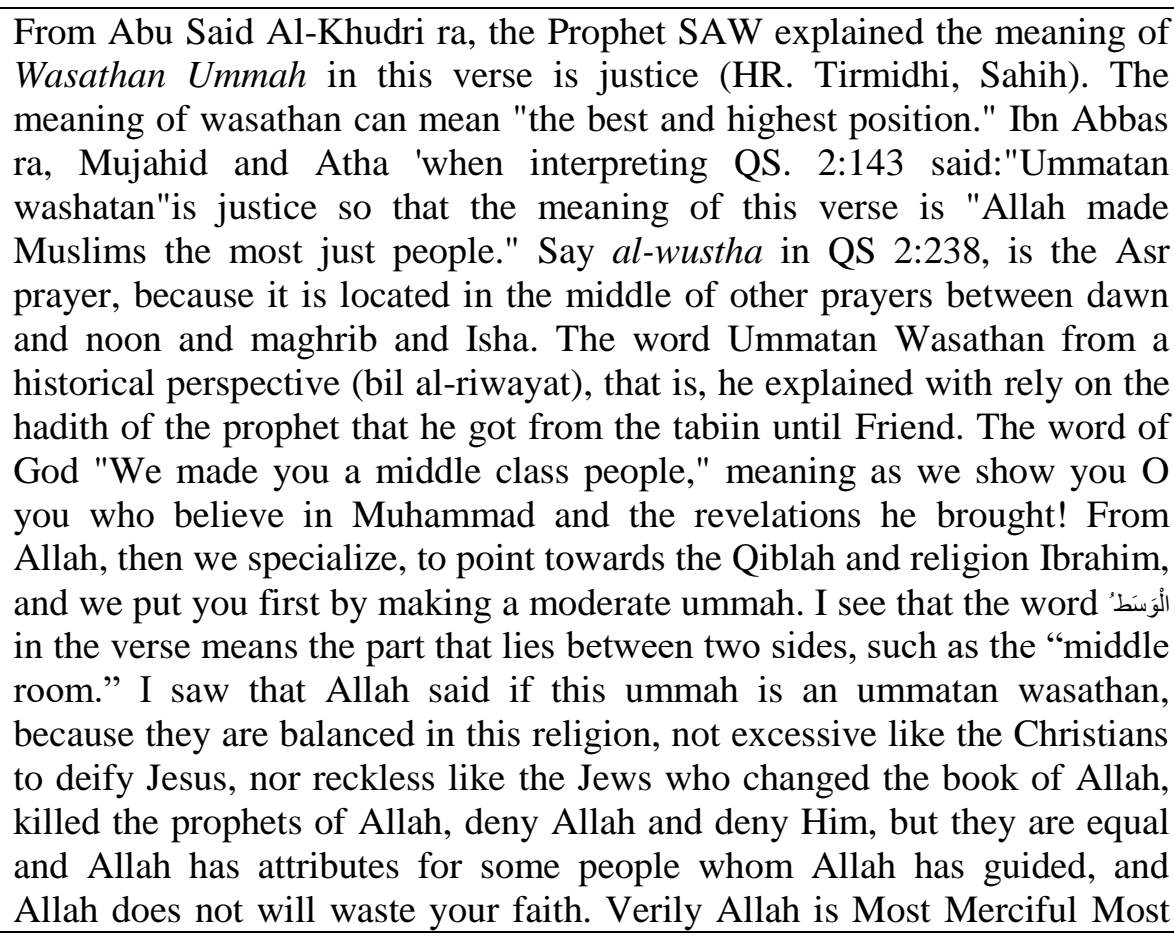 \\
\hline
\end{tabular}

Ibn Jarir At-Tabari, 2004, Tafsir At-Tabari, vols 2-8,. p.7 and vol. 16, p.567 dam 602, Cairo: Maktabah AtTaufiqiya. 


\begin{tabular}{|c|c|c|}
\hline & & 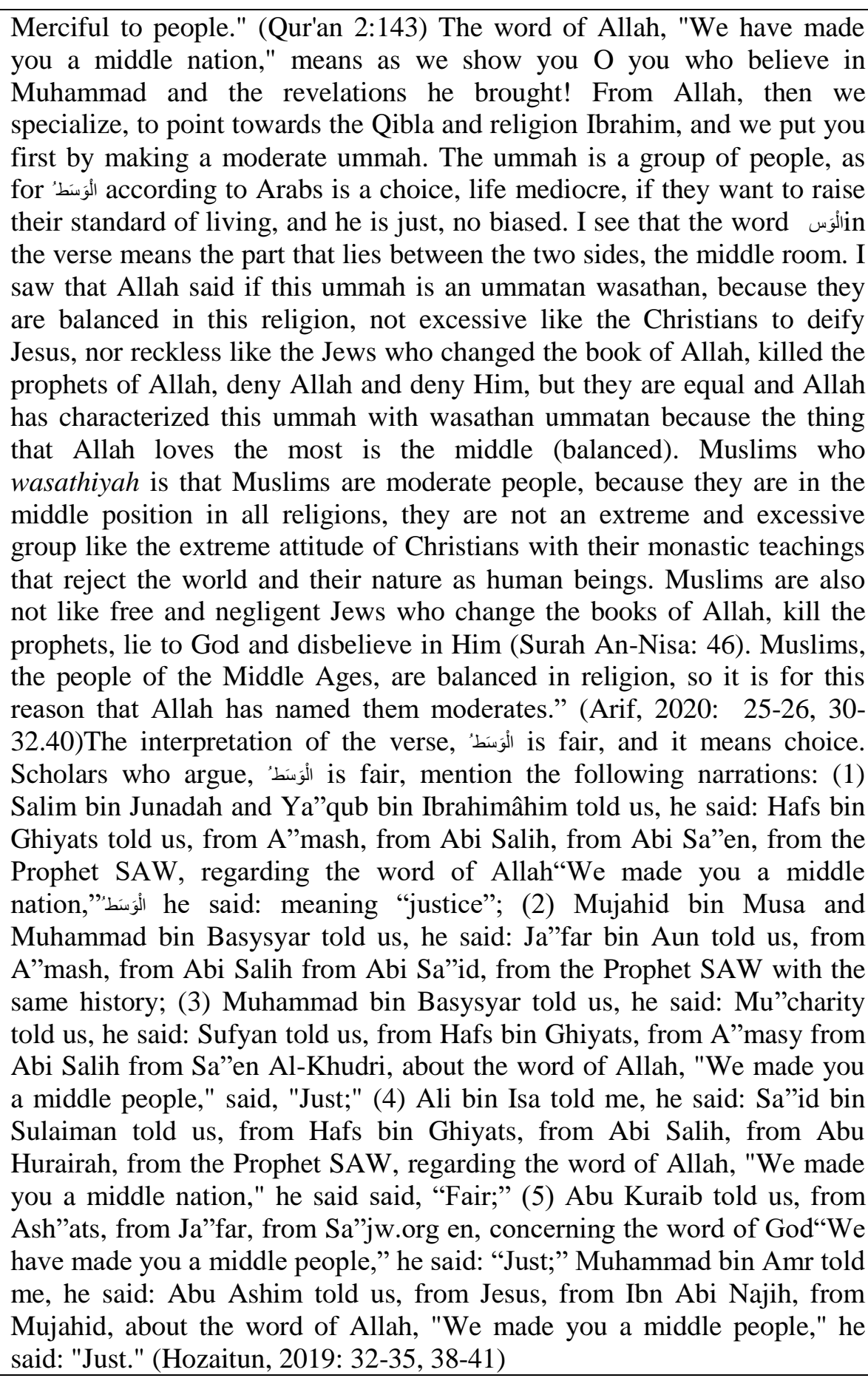 \\
\hline & Az-Zuhaili & $\begin{array}{l}\text { According to Wahbah Zuhaili, what is meant by Wasthan's Ummah are the } \\
\text { chosen people who can act fairly in all matters/cases. (Rizky \& Zakiah, } \\
\text { 2020: 3) }\end{array}$ \\
\hline \multicolumn{3}{|l|}{9} \\
\hline 10 & Ibn 'Assyria & $\begin{array}{l}\text { Ibn 'Asyur interprets Wasatiyah Islam with a very broad meaning. Written } \\
\text { research by Miftahudin wrote, that there are many Islam in Indonesia } \\
\text { groups and streams. There are many organizations in the name of Islam } \\
\text { (Ormas) each of which has a different interpretation meaning with other } \\
\text { Islamic organizations. With the many faces of Islam in Indonesia, tolerance } \\
\text { between people religious people should not be eliminated. Afrizal Nurdan } \\
\text { Mukhlis Lubis (2015) quotes Sheikh Jabir al-Jazâiri and Ibnu'Assyria has a }\end{array}$ \\
\hline
\end{tabular}




\begin{tabular}{|c|c|c|}
\hline & & $\begin{array}{l}\text { different meaning regarding Wasathiyah Islam itself. Al-Jazairiy as a } \\
\text { commentator who consistently maintains the noble values of ma'ruf } \\
\text { interpretation'tsur, the indicator is still consistent with the interpretation put } \\
\text { forward by senior scholars such as Ibn Kathir. (Hozaituna, 2019:6-7) }\end{array}$ \\
\hline 11 & Ibn Kathir & $\begin{array}{l}\text { Wasathan In this verse it means the best and the most qualified. (Arif, } \\
\text { 2020: 25-26).Asbabul Nuzul QS. al-Baqarah/2: 143. Before its } \\
\text { descentQS.2:143, the first verse that came down was QS.2:144, as the } \\
\text { narration explains, Muhammad bin Ishaq narrated from al-Bara' that the } \\
\text { Messenger of Allah. When praying still facing Baitul Maqdis he often set } \\
\text { his sights to the sky waiting for Allah's orders. So Allah swt. } \\
\text { lowerQS.2:144; "Indeed We (Allah often) see your face looking up to the } \\
\text { sky, so We (Allah) will turn you (Prophet Muhammad) to the Qibla that } \\
\text { you (Prophet Muhammad) like. Turn your face towards the Grand Mosque } \\
\text { (Ka'bah)..." Al-Bara' continued his words: "So some of the Muslims said: } \\
\text { "We want information about people (Muslims) who died before we faced } \\
\text { the Kaaba.'bah. And what about our prayers facing the Baitul Maqdis?" So } \\
\text { Allah (SWT) sent down a letterQS.2:143; "... and Allah will not waste your } \\
\text { faith (O Muslims)..." Those who lack understanding among mankind, they } \\
\text { are People of the Book (Jews and Christians) asked; "What causes them } \\
\text { (Muslims) to turn away from their Qibla (Baitul Maqdis) first?" So Allah } \\
\text { (SWT) sent downQS.2:142; "Those who lack sense among men will } \\
\text { say..." Until the endQS.2:143. (Mide, 2014: } 32-33 \text { ).Allah Ta"ala said: } \\
\text { "And so (also) We have made you (Muslims), a just and chosen people so } \\
\text { that you are witnesses of (deeds) humans and that the Messenger } \\
\text { (Muhammad) be witnesses of (deeds) you. Allah Ta'as said, "Indeed, We } \\
\text { have changed your Qibla to mecca of Ibrahim } \square \text { m (Ka"bah). We choose } \\
\text { the Qibla for you so that We make you as a chosen people, and on the Day } \\
\text { of Resurrection you will be witnesses over other peoples, because all the } \\
\text { people recognize your superiority." When Allah made this ummah as } \\
\text { Ummat Wasa } \square \text { an, then He gave speciality to him with Shari'ah" the most } \\
\text { perfect, the straightest path, and the clearest understanding. (Hozaituna, } \\
\text { 2019:2-3, 31) }\end{array}$ \\
\hline 12 & Ibn Tay & $\begin{array}{l}\text { Muslims are called wasath people because they are not excessive and } \\
\text { extreme towards their prophets. Moderate Muslims do not equate the } \\
\text { prophets as God and make the attributes of the prophets as divine } \\
\text { attributes, then worship them and make them healers of disease. Nor do } \\
\text { Muslims ignore the Prophets as messengers of Allah, reject them and } \\
\text { disobey them, but Muslims respect the Prophets, follow their Shari'ah and } \\
\text { help their religion". (Yusuf Al-Qardhawi, Fiqh Al-Wasathiyah Wa at- } \\
\text { tajdid, p.64) Ibn Taymiyya argues that wasathiyah This ummah lies in the } \\
\text { problem of cleanliness and uncleanness, on the issue of halal and haram } \\
\text { and on the issue of morals or morality. It was never the case that Islamic } \\
\text { teachings became hard and rigid during the Salaf generation and there was } \\
\text { never an attitude of making Islam easy during the Khalaf generation, } \\
\text { therefore only the enemies of Allah made this religion extreme and only } \\
\text { the guardians of Allah made this religion full of mercy and love. Dear". } \\
\text { Even Ibn Taymiyya is of the opinion that anyone who goes out or violates } \\
\text { the middle things in a person, then he has done the work of heresy of } \\
\text { ignorance." (Arif, 2020: 32) }\end{array}$ \\
\hline 13 & $\begin{array}{l}\text { Muhammad } \\
\text { Abduh }\end{array}$ & $\begin{array}{l}\text { Ummah in the Qur'an as mentioned in chapter } 2 \text { that the word ummah is } \\
\text { found in } 24 \text { letters and is repeated } 64 \text { times with several variants. Among } \\
\text { these verses, Muhammad Abduh explained that the ummah in his } \\
\text { interpretation of Surah Ali-Imran verse } 104 \text {. The Ummah is a society that } \\
\text { has strong bonds, which are bound by a unified vision and mission so that }\end{array}$ \\
\hline
\end{tabular}




\begin{tabular}{|c|c|}
\hline & 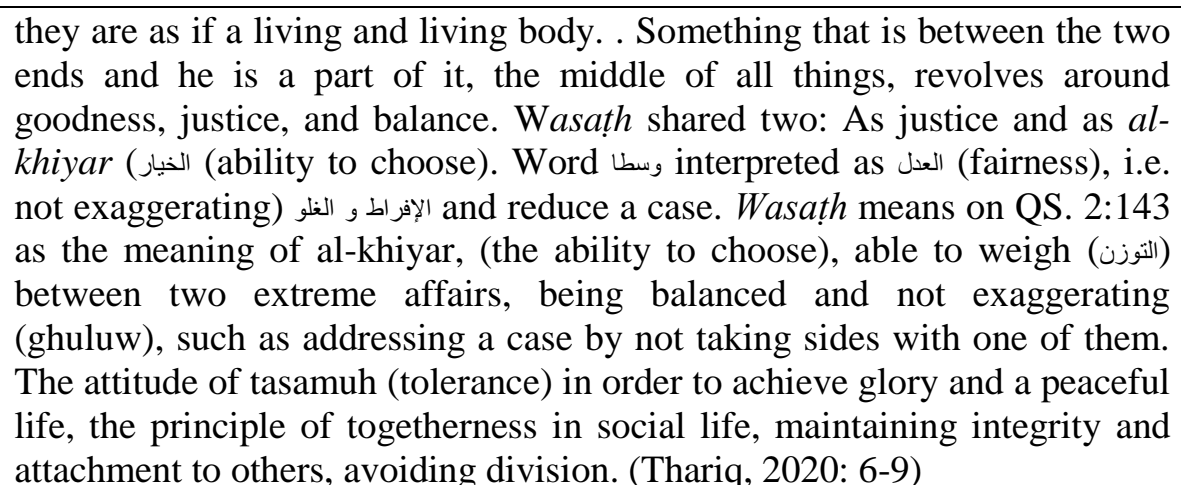 \\
\hline Rashid Rida & 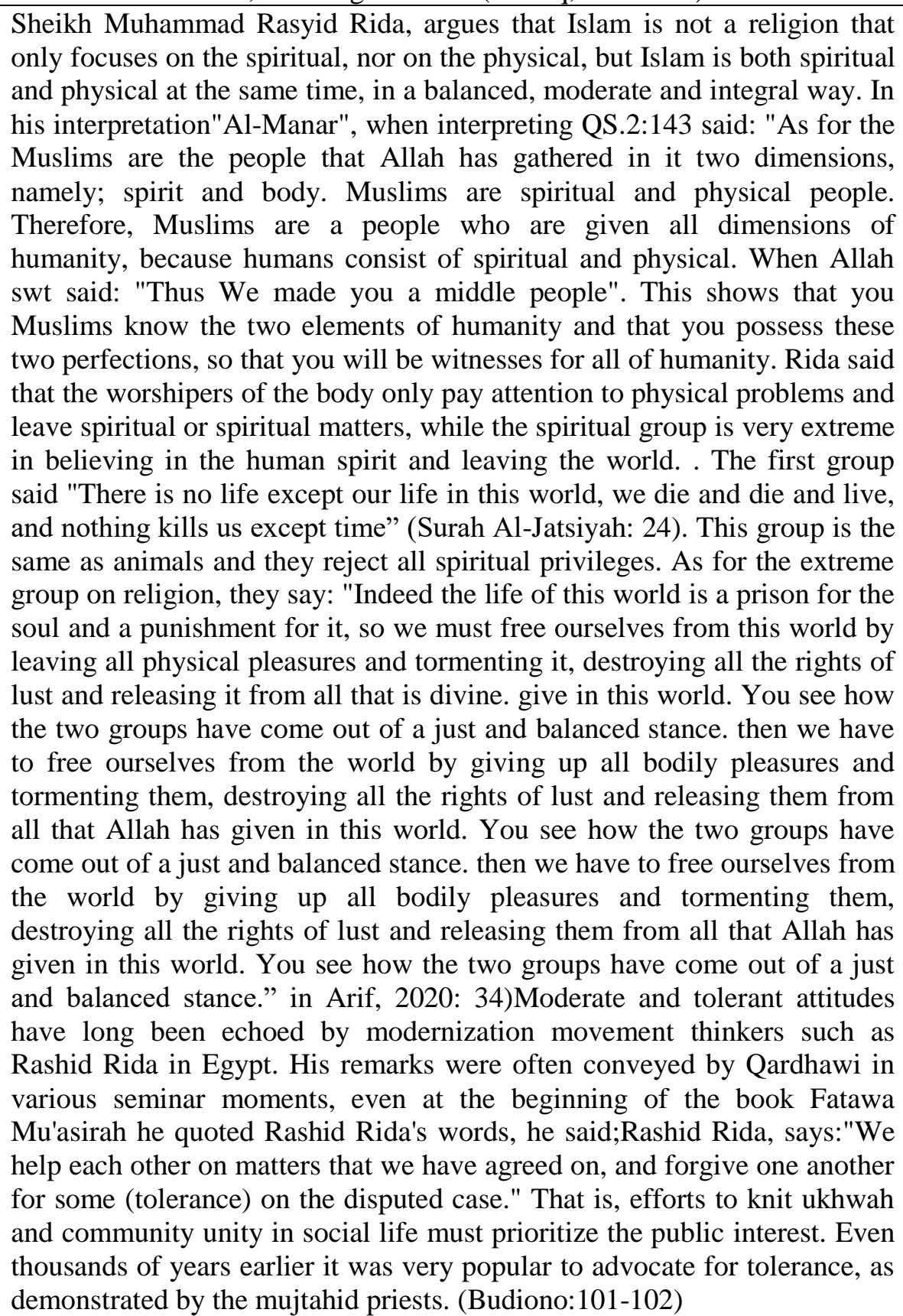 \\
\hline
\end{tabular}


From the table above, it can be explained that of the 15 commentators/ulama regarding QS.2:143, all of which have something to do with religious moderation. Although there are different interpretations in interpreting the term wasatan, the mufassirin scholars, as expressed in the studies published in the last 10 years, have discussed quite a lot about religious moderation and the moderate attitude possessed by Muslims in relation to interpretations.QS.2:143. From the studies presented above, it can be seen that some studies only focus on the meaning of wasath and quite minimally describe the meaning of Muslims in terms of ummah. From the table presented above, it can also be identified the various interpretations of the scholars from the past to the contemporary regarding the interpretation of the Qur'anQS.2:143.

\section{Conclusion}

From published research sources reviewed in this study, it can be concluded several points as follows:

1. In general, judging from the munasabah verse, QS al Baqarah (2): 143 relates to the attitude of the Jews and Christians in terms of changing the direction of the Qibla.

2. The meaning of ummah describes a group of people. While wasathan is a special characteristic/attribute of Allah SWT, which means justice, balance and peace. Ummatan wasathan is a process of proving the truth of the holy verses of the Qur'an that in the course of history, Muslims are the best, just and peace-loving religion.

3. Various studies reviewed on this SLR show that the mufassirins interpret the meaning of lafazh ummatan wasathan as having relevance to the meaning of moderation, including religious moderation.

\section{References}

143, Program Magister, Jurusan Aqidah Filsafat Islam Konsentrasi

Afrizal dan Mukhlis. (2005). Konsep Wasathiyah Dalam Al-Qur'an: Studi Airlangga, Surabaya, ISBN: 978-623-7522-41-6.

Al Alusi Al Baghdadi. (2001). Shihab al-Din al-Sayyid Mahmud. Ruh al-

Al Jawziyyah, Ibn Qayyim, tt. I'lam al-Muwaqqi' in 'an Rabb al-'Alamin, Vol.

Al Sabt, Khalid ibn Uthman. (2003). Qawa>id al-Tafsi>r Jam"an wa

Al-Qur'an: Komparasi Penafsiran Ibn Jârîr Al-țabârî dan Ibnu Asyûr, Program Studi Ilmu Al-Qur'an Dan Tafsir Fakultas Ushuluddin Univeritas Islam Negeri Syarif Hidayatullah, Jakarta

Alwi, Hasan, et al. (2007). Kamus Besar Bahasa Indonesia. Jakarta: Balai

Arif, Khairan Muhammad. (2020). Moderasi Islam (Wasathiyah Islam)

Ar-Raniry, Banda Aceh, Indonesia, Jurnal Ilmiah Al-Mu'ashirah

Ayat 143 Menurut Ibn Kathir dan Hamka, Prodi Ilmu Al-Qur'an dan Tafsir, Fakultas

Ushuluddin dan Filsafat Universitas Islam Negeri Sunan Ampel Surabaya

Aziz, Nasaiy. (2020). Islam dan Masyarakat Ideal (Ummatan Wasathan)

Budiono, Arif. (2001). Moderasi Beragama dalam Persfektif al Qur'an: Kajian Cet.XXV, Jakarta: Gramedia.

dalam ComTech, Vol. 5 No. 2 Desember 2014

dalam Perspektif Para Mufassir dan Relevansinya dengan Konteks

dalam QS. al-Baqarah (2): 143, Prodi Ilmu al-Qur'an dan Tafsir

dan Diklat Kementerian Agama Republik Indonesia

Departemen Pendidikan Nasional, 2008. Kamus bahasa Indonesia, 2008, 
Departemen Pendidikan Nasional, Jakarta: Pusat Bahasa.

Dirasatan, Vol. I, Mekkah: Daar ibn al-Qayyim

DOI: https://doi.org/10.34005/alrisalah.v11i1.592

Dozan, Wely. (2020). Islam Wasthiyyah dalam Perspektif Al-Qur'an: Kajian

Echols, John M., dan Shadilly, Hassan, 2003. Kamus Inggris Indonesia,

Hariyati, Rr. Tutik Sri. (2010). Mengenal Sistematic Review Theory Dan Studi

Hasbiansyah, O.(2008). Pendekatan Fenomenologi: Pengantar Praktik

Hozaituna, Rizkiyatun (2019/1140 H). Konsep Ummatan Wasaţan dalam

Hukum Ekonomi Syariah Fakultas Agama Islam, Universitas

Ibrahim, Thariq. (2020). Ummatan Wasatan dalam Tafsir Al-Manar: Penafsiran Ihya alTurath al-'Arabi.

III, Beirut: Dar al-Kutub al-Haditsah.Integrasi Keilmuan, Nidya Nia Ichiana, (ed.), cet.1, Gowa: Alauddin.

Islamic Communication, Vol. 1, No.1, Maret 2001; p-ISSN: 0000-0000; e-ISSN: 00000000; 85-116

Jabbar, M. Dhuha Abdul \& Burhanuddin, N., 2012. Ensiklopedia Makna al-Jakarta: Pusat Bahasa, Depdiknas.

Jurusan Tafsir Hadis pada Fakultas Ushuluddin, Filsafat dan Kasus, Jurnal Keperawatan Indonesia, 13 (2), Juli 2010, 124-133 Keindonesiaan Masa Kini dan Depan, Prodi Hukum Keluarga, UIN

Kementerian Agama RI. (2019). Moderasi Beragama, Cet.1, Badan Litbang

Komparatif Antara Tafsir At-Tahrir Wa At-Tanwir Dan Aisar At-Tafsir, Jurnal An-Nur, Vol. 4, No. 2 Tahun 2015.

Ma'ani fi Tafsir al-Qur'an al-'Azhim wa al-Sab'i al-Matsani, Beirut: Dar

Mide, Sabri. (2014). Ummatan Wasatan dalam al-Qur’an (Kajian Tafsir Tahlili

Muhammad Abduh Terhadap Surat Al-Baqarah: 143, Program Studi

Muhammadiyah Surakarta (h.6-9)

No.1, Juni 2008.

Nurdiani, Nina. (2014). Teknik Sampling Snowball dalam Penelitian Lapangan,

Nursalam et al. (2020). Pedoman Penyusunan Literature dan Systematic Penelitian dalam Ilmu Sosial dan Komunikasi, dalam Mediator Vol. 9.

Perspektif Al-Qur'an, As-Sunnah Serta Pandangan Para Ulama Dan Fuqaha, Al Risalah: Jurnal Studi Agama dan Pemikiran Islam, Vol 11 No 1 (2020), 22-43, Politik UIN Alauddin Makassar

Qasim, Muhammad, 2020. Membangun Moderasi Beragama Umat Melalui Qur'an Syarah al Faazhul Qur'an, Cet.I, Bandung: Fitrah Rabbani.Review, Priyantini, Diah (ed.), Fakultas Keperawatan Universitas

Ridho, Maufuroh, 2017. Ummatan Wasathan dalam Surat Al-Baqarah Studi Qur'an Hadits, Universitas Islam Negeri Sunan Kalijaga

Tafsir Surah al Baqarah: 143, JADID: Journal of Quranic Studies and Teks, Konteks, dan Kontekstualisasi Penafsiran Q.S. Al-Baqarah:

Tim Penyusun Kamus Pusat Bahasa, 2008. Kamus Bahasa Indonesia, Vol. 17. No.1 Januari 2020, p-ISSN: 1693-7562, e-ISSN: 2599-2619, 1-Yogyakarta 